\title{
No Association of Leptin Receptor Gene Gln223Arg Polymorphism with Capillary Glucose Levels: A Preliminary Population Base Cross-Sectional Study
}

\author{
Geórgia das Graças Pena, ${ }^{1}$ Andre Luiz Sena Guimarães, ${ }^{2}$ Rosângela Ramos Veloso, \\ Tatiana Carvalho Reis, ${ }^{2}$ João Felício Rodrigues Neto, ${ }^{2}$ and Gustavo Velasquez-Melendez ${ }^{1}$ \\ ${ }^{1}$ Departamento de Enfermagem Materno-Infantil e Saúde Pública, Escola de Enfermagem, Universidade Federal de Minas Gerais, \\ 30130100 Belo Horizonte, MG, Brazil \\ ${ }^{2}$ Departamento de Odontologia, Programa de Ciências da Saúde, Universidade Estadual de Montes Claros, 39401001 Montes Claros, \\ MG, Brazil
}

Correspondence should be addressed to Gustavo Velasquez-Melendez; jguveme@gmail.com

Received 14 June 2013; Accepted 17 July 2013

Academic Editors: B.-H. Jeong, M. Stemmler, and D. Sun

Copyright (C) 2013 Geórgia das Graças Pena et al. This is an open access article distributed under the Creative Commons Attribution License, which permits unrestricted use, distribution, and reproduction in any medium, provided the original work is properly cited.

\begin{abstract}
The leptin receptor gene has been reported to associate with insulin and glucose metabolism and adiposity in different study settings and various populations. Therefore, the aim of the study was to investigate the associations of the leptin receptor gene Gln223Arg polymorphism (LEPR Gln223Arg) with high capillary glucose levels. Cross-sectional study with probabilistic sample was carried out in individuals aged $\geq 18$ years in an urban area of Montes Claros, MG, Brazil. The capillary glucose was considered high when $\geq 140 \mathrm{mg} / \mathrm{dL}$. The genotypes of LEPR Gln223Arg distribution were as the following: $10.43 \% \mathrm{GG}(n=49), 46.81 \% \mathrm{AG}(n=220)$, and $42.77 \%$ AA $(n=201)$, and there were no prevalence differences between genders, $(P=0.57)$. Multivariate-adjusted models showed that there is no association between the polymorphism LEPR Gln223Arg and capillary high levels of glucose even when adjusted for age, sex, smoking, schooling, and parental history of obesity. In conclusion, no association between the polymorphism LEPR Gln223Arg and elevated blood glucose levels was detected.
\end{abstract}

\section{Introduction}

The leptin hormone is an adipocyte-specific ob gene product that regulates the energy balance and multifaceted biological actions and performs its central effects through several neuroendocrine systems [1]. There are multiple lines of evidence with regard to the association between variants of the gene encoding the leptin receptor and the metabolism of the hormone, a certain degree affecting the biological function and serum leptin [2-5]. In this sense, specifically leptin receptor gene Gln223Arg polymorphism (LEPR Gln223Arg) has been mentioned as one of the factors of genetic predisposition to overweight and other cardiometabolic events $[4,6-10]$ and as suggesting that obesity that genetic variation plays a leptinresistance [11]. Since the LEPR Gln223Arg has a functional importance for obesity, it could play a significant role in type 2 diabetes mellitus and pathophysiology of human obesity [12]. Furthermore, they may share a common genetic background; that is, the risk alleles for obesity may also be involved in the increased risk of developing type 2 diabetes [13, 14]. Studies with the leptin receptor, it will be important to clarify the functionality of different genetic variants, since several studies have found significant associations linking them to several traits of obesity, diabetes or the metabolic syndrome $[10,13]$. For our knowledge, no data are yet available in Brazil on the association of the LEPR Gln223Arg genotypes and capillary glucose levels as a proxy of impaired metabolism glucose. In the present study, we investigated the association between LEPR Arg223Gln polymorphism and the glucose levels in a preliminary population-based study from urban population. 


\section{Methods}

2.1. Study Population and Design. A cross-sectional population-based study was conducted with inhabitants aged $\geq 18$ years in Montes Claros, MG, Brazil. Montes Claros now has about 361.915 inhabitants; $95.1 \%$ of them in the urban area of the municipality [15].

2.2. Sample Design. This research proposes the sample size procedure for estimating the prevalence of the LEPR Gln223Arg. To draw the sample, we use cluster sampling method in two stages with unequal selection probabilities form the city of Montes Claros, MG state, Brazil. The sample size was based on the expected prevalence of $10 \%$ of the less frequent polymorphism [16] with the standard deviation of 1.55 and variation coefficient of $15 \%$. In the first stage, we used the database of census tracts (2010 Census, IBGE) [15] for the purpose of drawing the primary sampling units. On the second stage, we will use the address list for the purpose of drawing households, and all individuals found at the time of the survey were asked to participate in the study.

This study was approved by the Research Ethics Committee of Universidade Federal de MG (UFMG), and all participants gave written informed consent. In the first stage, we used the database of census tracts (2010 Census, IBGE) [15] for the purpose of drawing households.

Interview was conducted by answered a face-to-face survey questionnaire covering various aspects of their demographic (sex, age, skin color, marital status, and schoolarity) and lifestyle characteristics (physical activity, smoking habits, and alcohol consumption). At the conclusion of the interview, a clinical evaluation of participants was performed which included weight, height, waist circumference, and blood pressure measurements, carried out in triplicate by welltrained staff according to standard procedures [17, 18].

Weight and height were measured according to the recommendations of the World Health Organization, and it included all eligible participants in the selected households [18]. Capillary whole blood was obtained from a finger prick form all subjects in non-fasting status. This drop was placed on the tape reading in disposable and was immediately analyzed using Accucheck Roche (Mannheim, Germany) blood glucose analyzer. Participants were then divided into two categories considered those with high blood glucose values were $\geq 140 \mathrm{mg} / \mathrm{dL}$ with capillary whole blood glucose less than that value [19].

Blood pressure was measured, using an ONRON HEM742INT (SP, Brazil) automatic BP monitor, in the sitting position, using the right upper arm and an appropriately sized cuff after 5 minutes, according to The Seventh Report of the Joint National Committee on Prevention, Detection, Evaluation, and Treatment of High Blood Pressure [17]. Measurements were accomplished three times in the participant right arm with a two-minute interval, after an at least fiveminute rest. Hypertension was defined as a systolic blood pressure greater than or equal $140 \mathrm{mmHg}$ and/or a diastolic blood pressure greater than or equal to $90 \mathrm{mmHg}$ or reported use of medication for hypertension control [17].
2.3. DNA Extraction. DNA was extracted from oral mucosa scraping from study participants. DNA samples were isolated using silica particles, which are adsorbed to DNA. Then, DNA was washed to remove impurities, and it was eluted in TE buffer, as previously described [20].

Leptin receptor gene polymorphism LEPR Gln223Arg (A > G; rs1137101) was assessed by restriction fragment length polymorphism-polymerase chain reaction (RFLPPCR). Polymerase chain reaction for LEPR gene was performed on $500 \mathrm{ng}$ of genomic DNA, as template. Other reagents were used, including $4 \mu \mathrm{M}$ of each primer (F: 5'-ACCCTTTAAGCTGGGTGTCCCAAATAG-3'; R: $5^{\prime}$ CAATATTTATGGGCTG AACTGACATT-3'; $330 \mathrm{bp}$ ), $0.1 \mathrm{mM}$ of each DNTP (Amersham Biosciences, Pittsburg, PA, USA), 1X PCR buffer, $2.5 \mathrm{mM}$ magnesium chloride, and $2.5 \mathrm{U}$ of Platinum Taq DNA polymerase (Invitrogen Life Technologies, Carlsbad, CA, USA). The 330 bp PCR product was digested with MspI (HPAII) restriction endonuclease (Fermentas Life Sciences, Lithuania), that recognizes the restriction site (C/CGG). For this SNP, the A allele lacks MspI restriction site. Thus, individuals carrying $A$ allele show only one PCR product ( $330 \mathrm{bp}$ ), while those who carry G allele show two bands (293 and $37 \mathrm{bp}$ ). Positive control for digestion reaction was used, and $10 \mu \mathrm{L}$ amplified DNA was digested with $1.0 \mathrm{U}$ of $\mathrm{MspI}$ for $16 \mathrm{~h}$ at $37^{\circ} \mathrm{C}$. PCR and restriction reactions were performed into a thermocycler (Eppendorf AG, Hamburg, Germany). The products PCR were visualized by electrophoresis in $10 \%$ acrylamide gel stained with silver.

\section{Statistical Analyses}

The $\chi^{2}$ test or Fisher's exact test have been performed to compare categorical variables, and Student's $t$-test has been performed to compare age as a continuous variable. All analyzes have been performed using Stata version 12.0 (Stata Corp, Texas, USA) and results with $P<0.05$ have been considered statistically significant. Afterward variables with $P<0.05$ have been entered into multivariate logistic regression analysis with the forward elimination method, and adjusted odds ratio (OR) and 95\% confidence interval (CI) in order to explore the association between the Gln2234Arg polymorphism and capillary glucose levels.

\section{Results}

This cross-sectional study recruited 470 participants; the mean and standard deviation of age with average age of total population were $44.72 \pm 17.99$ years; $34.2 \%$ (161) of participants were males; and 65.7\% (309) were females. Selected demographic characteristics and adiposity traits according to gender are shown in Table 1 . The age group with the highest frequency was from 18 to 29 years $25 \%$ (119) followed by age greater or equal to 60 years $21 \%$ (101). Frequencies of schooling equal to or greater than 9 years of education and income were similar between the sexes. There were no statistically differences in sociodemographic characteristics between genders, except for the marital status. For the lifestyle variables, the consumption of alcohol and tobacco was higher 
TABLE 1: Sociodemographic characteristics by sex.

\begin{tabular}{|c|c|c|c|c|c|c|c|}
\hline \multirow{3}{*}{ Variable } & \multicolumn{4}{|c|}{ Sex } & & & \multirow{3}{*}{$P$ value* } \\
\hline & \multicolumn{2}{|c|}{ Male } & \multicolumn{2}{|c|}{ Female } & \multicolumn{2}{|c|}{ Total } & \\
\hline & $n$ & $\%$ & $n$ & $\%$ & $n$ & $\%$ & \\
\hline \multicolumn{8}{|l|}{ Age groups (years) } \\
\hline $18-29$ & 40 & 24.84 & 79 & 25.57 & 119 & 25.32 & \multirow{5}{*}{0.472} \\
\hline $30-39$ & 30 & 18.63 & 52 & 16.83 & 82 & 17.45 & \\
\hline $40-49$ & 20 & 12.42 & 58 & 18.77 & 78 & 16.60 & \\
\hline $50-59$ & 34 & 21.12 & 56 & 18.12 & 90 & 19.15 & \\
\hline$\geq 60$ & 37 & 22.98 & 64 & 20.71 & 101 & 21.49 & \\
\hline \multicolumn{8}{|l|}{ Skin color } \\
\hline White & 26 & 16.25 & 73 & 23.70 & 99 & 21.15 & \multirow[t]{2}{*}{0.061} \\
\hline Nonwhite & 134 & 83.75 & 235 & 76.30 & 369 & 78.85 & \\
\hline \multicolumn{8}{|l|}{ Marital status } \\
\hline With spouse & 106 & 65.84 & 140 & 45.31 & 246 & 52.34 & \multirow[t]{2}{*}{$<0.001$} \\
\hline Without spouse & 55 & 34.16 & 169 & 54.69 & 224 & 47.66 & \\
\hline \multicolumn{8}{|l|}{ Education (years) } \\
\hline$<5$ & 19 & 11.88 & 52 & 16.88 & 71 & 15.71 & \multirow{4}{*}{0.410} \\
\hline$\geq 5$ and $<8$ & 68 & 42.50 & 118 & 38.31 & 186 & 39.74 & \\
\hline$\geq 8$ e $<12$ & 24 & 15.00 & 38 & 12.34 & 62 & 13.25 & \\
\hline$\geq 12$ & 49 & 30.62 & 100 & 32.47 & 149 & 31.84 & \\
\hline \multicolumn{8}{|l|}{ Income (minimum wages) } \\
\hline$<2$ & 25 & 15.53 & 44 & 14.29 & 69 & 14.71 & \multirow{3}{*}{0.251} \\
\hline$\geq 2 \mathrm{a}<4$ & 74 & 45.96 & 121 & 39.29 & 195 & 41.58 & \\
\hline$\geq 4$ & 62 & 38.51 & 143 & 46.42 & 205 & 43.71 & \\
\hline \multicolumn{8}{|l|}{ Physical activity } \\
\hline Yes & 113 & 70.19 & 239 & 77.35 & 352 & 74.89 & \multirow[t]{2}{*}{0.089} \\
\hline Inactive & 48 & 29.81 & 70 & 22.65 & 118 & 25.11 & \\
\hline \multicolumn{8}{|l|}{ Smoking } \\
\hline Yes & 32 & 20.00 & 16 & 5.23 & 48 & 10.30 & \multirow{3}{*}{$<0.001$} \\
\hline Ex-smoking & 43 & 26.87 & 35 & 11.44 & 78 & 16.74 & \\
\hline No & 85 & 53.13 & 255 & 83.33 & 340 & 72.96 & \\
\hline Alcohol intake & & & & & & & \\
\hline Yes & 60 & 37.27 & 81 & 26.21 & 141 & 30.00 & 0.013 \\
\hline No & 101 & 62.73 & 228 & 73.79 & 329 & 70.00 & \\
\hline Nutritional status & & & & & & & \\
\hline Underweight & 08 & 4.97 & 13 & 4.23 & 21 & 4.49 & \\
\hline Normal weight & 73 & 45.34 & 123 & 40.07 & 196 & 41.88 & 0.099 \\
\hline Overweight & 54 & 33.54 & 90 & 29.32 & 144 & 30.77 & \\
\hline Obese & 26 & 16.15 & 81 & 26.38 & 107 & 22.86 & \\
\hline Abdominal obesity & & & & & & & \\
\hline No & 135 & 83.85 & 178 & 57.79 & 313 & 66.74 & $<0.001$ \\
\hline Yes & 26 & 16.15 & 130 & 42.21 & 156 & 33.26 & \\
\hline Hypertension & & & & & & & \\
\hline Yes & 96 & 59.63 & 176 & 57.33 & 272 & 58.12 & 0.632 \\
\hline No & 65 & 40.37 & 131 & 42.67 & 196 & 41.88 & \\
\hline History of parent's obesity & & & & & & & \\
\hline Yes & 144 & 89.44 & 262 & 85.06 & 406 & 86.57 & 0.187 \\
\hline No & 161 & 10.56 & 46 & 14.94 & 63 & 13.43 & \\
\hline Glucose level & & & & & & & \\
\hline Normal (<140 mg/dL) & 137 & 85.09 & 267 & 86.97 & 404 & 86.32 & 0.574 \\
\hline $\operatorname{High}(\geq 140 \mathrm{mg} / \mathrm{dL})$ & 24 & 14.91 & 40 & 13.03 & 64 & 13.68 & \\
\hline
\end{tabular}

${ }^{*}$ Chi-square test. 
TABLE 2: Sociodemographic characteristics by glucose level.

\begin{tabular}{|c|c|c|c|c|c|c|c|}
\hline \multirow{3}{*}{ Variable } & \multicolumn{4}{|c|}{ Glucose level } & & & \multirow{3}{*}{$P$ value ${ }^{*}$} \\
\hline & \multicolumn{2}{|c|}{ Normal $<140 \mathrm{mg} / \mathrm{dL}$} & \multicolumn{2}{|c|}{ High $\geq 140 \mathrm{mg} / \mathrm{dL}$} & \multicolumn{2}{|c|}{ Total } & \\
\hline & $n$ & $\%$ & $n$ & $\%$ & $n$ & $\%$ & \\
\hline \multicolumn{8}{|l|}{ Age groups (years) } \\
\hline $18-29$ & 117 & 28.96 & 2 & 3.13 & 119 & 25.43 & \multirow{5}{*}{$<0.001$} \\
\hline $30-39$ & 78 & 19.31 & 4 & 6.25 & 82 & 17.52 & \\
\hline $40-49$ & 68 & 16.83 & 9 & 14.06 & 78 & 16.42 & \\
\hline $50-59$ & 71 & 79.78 & 18 & 28.14 & 90 & 19.02 & \\
\hline$\geq 60$ & 70 & 69.31 & 31 & 48.44 & 101 & 21.60 & \\
\hline \multicolumn{8}{|l|}{ Skin color } \\
\hline White & 79 & 19.65 & 20 & 31.25 & 99 & 21.24 & \multirow[t]{2}{*}{0.035} \\
\hline Nonwhite & 323 & 80.35 & 244 & 68.75 & 367 & 78.76 & \\
\hline \multicolumn{8}{|l|}{ Marital status } \\
\hline With spouse & 205 & 50.74 & 39 & 60.94 & 244 & 52.14 & \multirow[t]{2}{*}{0.129} \\
\hline Without spouse & 199 & 49.26 & 25 & 39.06 & 224 & 47.86 & \\
\hline \multicolumn{8}{|l|}{ Education (years) } \\
\hline$<5$ & 65 & 16.17 & 4 & 6.25 & 69 & 15.17 & \multirow{4}{*}{0.001} \\
\hline$\geq 5$ and $<8$ & 168 & 41.79 & 18 & 28.13 & 186 & 39.74 & \\
\hline$\geq 8$ e $<12$ & 54 & 13.43 & 8 & 12.50 & 62 & 13.30 & \\
\hline$\geq 12$ & 115 & 28.61 & 34 & 53.13 & 149 & 31.97 & \\
\hline \multicolumn{8}{|c|}{ Income (minimum wages) } \\
\hline$<2$ & 60 & 14.89 & 9 & 14.06 & 69 & 14.78 & \multirow{3}{*}{0.981} \\
\hline$\geq 2 \mathrm{a}<4$ & 166 & 41.19 & 27 & 42.19 & 193 & 41.33 & \\
\hline$\geq 4$ & 177 & 43.92 & 28 & 43.75 & 205 & 43.90 & \\
\hline \multicolumn{8}{|l|}{ Physical activity } \\
\hline Yes & 313 & 77.48 & 37 & 57.81 & 350 & 74.79 & \multirow[t]{2}{*}{0.001} \\
\hline Inactive & 91 & 22.52 & 27 & 42.19 & 118 & 25.21 & \\
\hline \multicolumn{8}{|l|}{ Smoking } \\
\hline Yes & 42 & 10.45 & 6 & 12.50 & 48 & 10.34 & \multirow{3}{*}{0.002} \\
\hline Ex-smoking & 57 & 14.18 & 20 & 25.97 & 77 & 16.59 & \\
\hline No & 303 & 75.37 & 36 & 58.06 & 339 & 73.06 & \\
\hline \multicolumn{8}{|l|}{ Alcohol intake } \\
\hline Yes & 128 & 31.68 & 13 & 20.31 & 141 & 30.13 & \multirow[t]{2}{*}{0.065} \\
\hline No & 276 & 68.32 & 51 & 79.69 & 327 & 69.87 & \\
\hline \multicolumn{8}{|l|}{ Nutritional status } \\
\hline Underweight & 19 & 4.73 & 2 & 3.13 & 21 & 4.51 & \\
\hline Normal weight & 174 & 43.28 & 21 & 32.81 & 195 & 41.85 & 0.012 \\
\hline Overweight & 127 & 31.59 & 16 & 25.00 & 16 & 30.69 & \\
\hline Obese & 82 & 20.40 & 25 & 39.06 & 25 & 22.96 & \\
\hline Abdominal obesity & & & & & & & \\
\hline No & 279 & 69.06 & 33 & 52.38 & 312 & 66.81 & 0.009 \\
\hline Yes & 125 & 30.94 & 30 & 47.62 & 155 & 33.19 & \\
\hline Hypertension & & & & & & & \\
\hline Yes & 254 & 63.18 & 16 & 25.00 & 270 & 57.94 & $<0.001$ \\
\hline No & 148 & 36.82 & 48 & 75.00 & 196 & 42.06 & \\
\hline
\end{tabular}

${ }^{*}$ Chi-square test.

in the male group $(P<0.05)$. The genotypes of Gln223Arg polymorphism in the LEPR gene distribution were as the following: GG genotype was $10.43 \%(n=49), 46.81 \%$ AG $(n=220)$, and $42.77 \%$ AA $(n=201)$ (data not shown).
The percentage of individuals having fasting blood glucose levels greater than or equal to $140 \mathrm{~g} / \mathrm{L}$ in our sample was $13.68 \%$ ( $n=64,95 \% \mathrm{CI}: 0.12-0.20)$. When the sample was distributed by glucose level was observed that age group, 
TABLE 3: Multivariate logistic odds ratio and confidence interval (95\% CI) of association between genotype and high capillary glucose levels $(\geq 140 \mathrm{mg} / \mathrm{dL})$.

\begin{tabular}{|c|c|c|c|}
\hline Capillary glucose $(\geq 140 \mathrm{mg} / \mathrm{dL})$ & OR & $95 \% \mathrm{CI}$ & $P$ value \\
\hline \multicolumn{4}{|l|}{ Model 1 (not adjusted) } \\
\hline Genotype GG & 1 & - & - \\
\hline Genotype AG & 0.83 & $0.34-2.05$ & 0.702 \\
\hline Genotype AA & 1.06 & $0.43-2.59$ & 0.889 \\
\hline \multicolumn{4}{|l|}{ Model 2 (adjust: age) } \\
\hline Genotype AG & 0.84 & $0.32-2.16$ & 0.721 \\
\hline Genotype AA & 0.88 & $0.79-2.26$ & 0.798 \\
\hline \multicolumn{4}{|l|}{ Model 3 (adjust: age and gender) } \\
\hline Genotype AG & 0.84 & $0.72-2.13$ & 0.724 \\
\hline Genotype AA & 0.89 & $0.34-2.28$ & 0.809 \\
\hline \multicolumn{4}{|c|}{ Model 4 (adjust: age, gender, and education) } \\
\hline Genotype AG & 0.87 & $0.33-2.27$ & 0.790 \\
\hline Genotype AA & 0.89 & $0.34-2.31$ & 0.824 \\
\hline \multicolumn{4}{|c|}{ Model 5 (adjust: age, gender, education, and smoke) } \\
\hline Genotype AG & 0.99 & $0.36-2.75$ & 0.999 \\
\hline Genotype AA & 1.01 & $0.37-2.75$ & 0.981 \\
\hline \multicolumn{4}{|c|}{ Model 6 (adjust: age, gender, education, smoke, and alcohol intake) } \\
\hline Genotype AG & 1.05 & $0.38-2.90$ & 0.917 \\
\hline Genotype AA & 1.02 & $0.37-2.80$ & 0.962 \\
\hline \multicolumn{4}{|c|}{ Model 7 (adjust: age, gender, education, smoke, alcohol intake, and WC) } \\
\hline Genotype AG & 1.00 & $0.36-2.77$ & 0.995 \\
\hline Genotype AA & 1.01 & $0.37-2.78$ & 0.976 \\
\hline \multicolumn{4}{|c|}{ Model 8 (adjust: age, gender, education, smoke, alcohol intake, WC, and parental history of obesity) } \\
\hline Genotype AG & 0.97 & $0.35-2.71$ & 0.968 \\
\hline Genotype AA & 1.00 & $0.36-2.76$ & 0.988 \\
\hline
\end{tabular}

WC: waist circumference.

skin color, schooling, physical activity, nutritional status, waist circumference and hypertension were associated with glucose levels excepted marital status, income and alcohol intake (Table 2). Neither in the univariate analysis nor in the multivariate analysis for the models adjusted by the potentially confounders (age, sex, schooling, smoking, alcohol intake and waist circumference) an association between the polymorphism LEPR Gln223Arg and elevated blood glucose levels was detected (Table 3 ).

\section{Discussion}

In this population-based study, we estimate the associations between genotype frequencies determined using PCR-RFLP analysis of the Gln223Arg polymorphism and the high capillary glucose levels. Several studies have described the associations with obesity, hypertension, or other chronic diseases [9, 21-23], but the conclusions about the glucose levels are not yet clear. The Gln223Arg polymorphism is within the region encoding the extracellular domain of the leptin receptor, and, therefore, the amino acid change affects all forms of the receptor. It has been shown that LEPR Gln223Arg polymorphism is associated with the variation in ligand binding; higher levels of ligand binding activity have been demonstrated in individuals homozygous for the
G (LEPR Arg223Arg) allele than in carriers of the A (LEPR $223 \mathrm{Gln}$ ) allele, and the leptin receptors in the hypothalamus and the pancreatic beta-cells could be where they mediate leptin-induced inhibition of insulin secretion [8]. Despite some studies have been found to be associated with diabetes and insulin homeostasis $[13,24]$. However, in this study, no association between the polymorphism LEPR Gln223Arg and elevated blood glucose levels was detected. This is similar to a previous study conducted in other populations in which the Gln223Arg in the leptin receptor was not associated with body weight, leptin concentration, and metabolic parameters $[13,25]$. Furthermore, the knowledge on the complex signaling pathways involved the insulin resistance and diabetes and could provide the foundation for improved clinical management of patients with metabolic diseases. The lack of association could be due to this complex pathogenesis of hyperglycemia which involves a numerous of genetic and environmental factors which other studies should attempt to control.

\section{Conclusions}

In summary, in this study, we report no association between Gln223Arg polymorphism and capillary whole glucose levels. This association remained insignificant after controlling 
many potentially confounders, and we did not measure leptin levels.

\section{Conflict of Interests}

The authors declared that there is no conflict of interests.

\section{Authors' Contribution}

Gustavo Velasquez-Melendez, João Felício Rodrigues Neto, Geórgia das Graças Pena, and Andre Luiz Sena Guimarães designed research; Gustavo Velasquez-Melendez, João Felício Rodrigues Neto, Geórgia das Graças Pena, Rosângela Ramos Veloso, and Tatiana Carvalho Reis conducted research; Gustavo Velasquez-Melendez, Geórgia das Graças Pena, and Andre Luiz Sena Guimarães analyzed data; Gustavo Velasquez-Melendez, Geórgia das Graças Pena, and Andre Luiz Sena Guimarães wrote the paper. Gustavo VelasquezMelendez and Geórgia das Graças Pena had primary responsibility for final content. All authors read and approved the final paper. All authors abide by the Association for Medical Ethics (AME) ethical rules of disclosure.

\section{Acknowledgments}

This study was supported by Grant (EFP_00001409) from the Fundação de Amparo a Pesquisa do Estado de MG (FAPEMIG). Dr. Guimarães and Dr. Velasquez-Melendez are research fellows of Conselho Nacional de Desenvolvimento Científico e Tecnológico (CNPq).

\section{References}

[1] P. Trayhurn, N. Hoggard, J. G. Mercer, and D. V. Rayner, "Leptin: fundamental aspects," International Journal of Obesity and Related Metabolic Disorders, vol. 23, supplement 1, pp. 2228, 1999.

[2] V. S. Mattevi, V. M. Zembrzuski, and M. H. Hutz, "Association analysis of genes involved in the leptin-signaling pathway with obesity in Brazil," International Journal of Obesity, vol. 26, no. 9, pp. 1179-1185, 2002.

[3] R. Rosmond, Y. C. Chagnon, G. Holm et al., "Hypertension in obesity and the leptin receptor gene locus," Journal of Clinical Endocrinology and Metabolism, vol. 85, no. 9, pp. 3126-3131, 2000.

[4] M. Wauters, I. Mertens, M. Chagnon et al., "Polymorphisms in the leptin receptor gene, body composition and fat distribution in overweight and obese women," International Journal of Obesity, vol. 25, no. 5, pp. 714-720, 2001.

[5] H.-Y. Woo, H. Park, C.-S. Ki, Y. L. Park, and W. G. Bae, "Relationships among serum leptin, leptin receptor gene polymorphisms, and breast cancer in Korea," Cancer Letters, vol. 237, no. 1, pp. 137-142, 2006.

[6] Y. C. Chagnon, W. K. Chung, L. Pérusse, M. Chagnon, R. L. Leibel, and C. Bouchard, "Linkages and associations between the leptin receptor (LEPR) gene and human body composition in the Québec Family Study," International Journal of Obesity, vol. 23, no. 3, pp. 278-286, 1999.

[7] Y. C. Chagnon, J. H. Wilmore, I. B. Borecki et al., "Associations between the leptin receptor gene and adiposity in middle-aged
Caucasian males from the HERITAGE family study," Journal of Clinical Endocrinology and Metabolism, vol. 85, no. 1, pp. 29-34, 2000.

[8] N. D. Quinton, A. J. Lee, R. J. M. Ross, R. Eastell, and A. I. F. Blakemore, "A single nucleotide polymorphism (SNP) in the leptin receptor is associated with BMI, fat mass and leptin levels in postmenopausal Caucasian women," Human Genetics, vol. 108, no. 3, pp. 233-236, 2001.

[9] N. Yiannakouris, M. Yannakoulia, L. Melistas, J. L. Chan, D. Klimis-Zacas, and C. S. Mantzoros, “The Q223R polymorphism of the leptin receptor gene is significantly associated with obesity and predicts a small percentage of body weight and body composition variability," Journal of Clinical Endocrinology and Metabolism, vol. 86, no. 9, pp. 4434-4439, 2001.

[10] K. G. Jackson, J. Delgado-Lista, R. Gill et al., “The leptin receptor Gln223Arg polymorphism (rs1137101) mediates the postprandial lipaemic response, but only in males," Atherosclerosis, vol. 225, no. 1, pp. 135-141, 2012.

[11] L. Attig, A. Vigé, A. Gabory et al., "Dietary alleviation of maternal obesity and diabetes: increased resistance to dietinduced ibesity transcriptional and epigenetic signatures," PLoS ONE, vol. 8, no. 6, Article ID e66816, 2013.

[12] P. Trayhurn, C. Bing, and I. S. Wood, "Adipose tissue and adipokines-energy regulation from the human perspective," Journal of Nutrition, vol. 136, no. 7, pp. 1935S-1939S, 2006.

[13] T. Salopuro, L. Pulkkinen, J. Lindström et al., "Genetic variation in leptin receptor gene is associated with type 2 diabetes and body weight: the Finnish Diabetes Prevention Study," International Journal of Obesity, vol. 29, no. 10, pp. 1245-1251, 2005.

[14] N. Y. Souren, A. D. Paulussen, A. Steyls et al., "Common SNPs in LEP and LEPR associated with birth weight and type 2 diabetesrelated metabolic risk factors in twins," International Journal of Obesity, vol. 32, no. 8, pp. 1233-1239, 2008.

[15] Instituto Brasileiro de Geografia e Estatística, "CENSO 2010," 2010, http://censo2010.ibge.gov.br/.

[16] C. C. Ragin, C. Dallal, M. Okobia et al., "Leptin levels and leptin receptor polymorphism frequency in healthy populations," Infectious Agents and Cancer, vol. 4, supplement 1, article S13, 2009.

[17] A. V. Chobanian, G. L. Bakris, H. R. Black et al., "The seventh report of the joint national committee on prevention, detection, evaluation, and treatment of high blood pressure: the JNC 7 report," Journal of the American Medical Association, vol. 289, no. 19, pp. 2560-2572, 2003.

[18] WHO, The Use and Interpretation of Anthropometry, World Health Organization, Geneva, Switzerland, 1995.

[19] WHO, Definition, Diagnosis and Classification of Diabetes Mellitus and Intermediate Hyperglycemia: Report of a WHo/IDf Consultation, World Health Organization, Geneva, Switzerland, 2006.

[20] A. L. S. Guimarães, A. R. de Sá, J. M. N. Victória et al., "Association of interleukin-1 $\beta$ polymorphism with recurrent aphthous stomatitis in Brazilian individuals," Oral Diseases, vol. 12, no. 6, pp. 580-583, 2006.

[21] P. Gu, W. Jiang, M. Chen et al., "Association of leptin receptor gene polymorphisms and essential hypertension in a Chinese population," Journal of Endocrinological Investigation, vol. 35, no. 9, pp. 859-865, 2012.

[22] M. T. Guagnano, M. R. Manigrasso, E. Ballone et al., "Association between serum leptin levels and 24-hour blood pressure 
in obese women," Obesity Research, vol. 11, no. 4, pp. 549-555, 2003.

[23] Y. Zheng, K. Xiang, R. Zhang, W. Jia, J. Lu, and J. Tang, "Association of Gln223Arg variant in leptin receptor gene with metabolic abnormalities and hypertension in type II diabetes mellitus in Shanghai "Han" population," Zhonghua Nei Ke Za Zhi, vol. 38, no. 3, pp. 174-177, 1999.

[24] T. A. Lakka, T. Rankinen, S. J. Weisnagel et al., "Leptin and leptin receptor gene polymorphisms and changes in glucose homeostasis in response to regular exercise in nondiabetic individuals: the HERITAGE family study," Diabetes, vol. 53, no. 6, pp. 1603-1608, 2004.

[25] Z. Komşu-Örnek, F. Demirel, A. Dursun, B. Ermiş, I. E. Pişkin, and A. Bideci, "Leptin receptor gene Gln223Arg polymorphism is not associated with obesity and metabolic syndrome in Turkish children," Turkish Journal of Pediatrics, vol. 54, no. 1, pp. 20-24, 2012. 

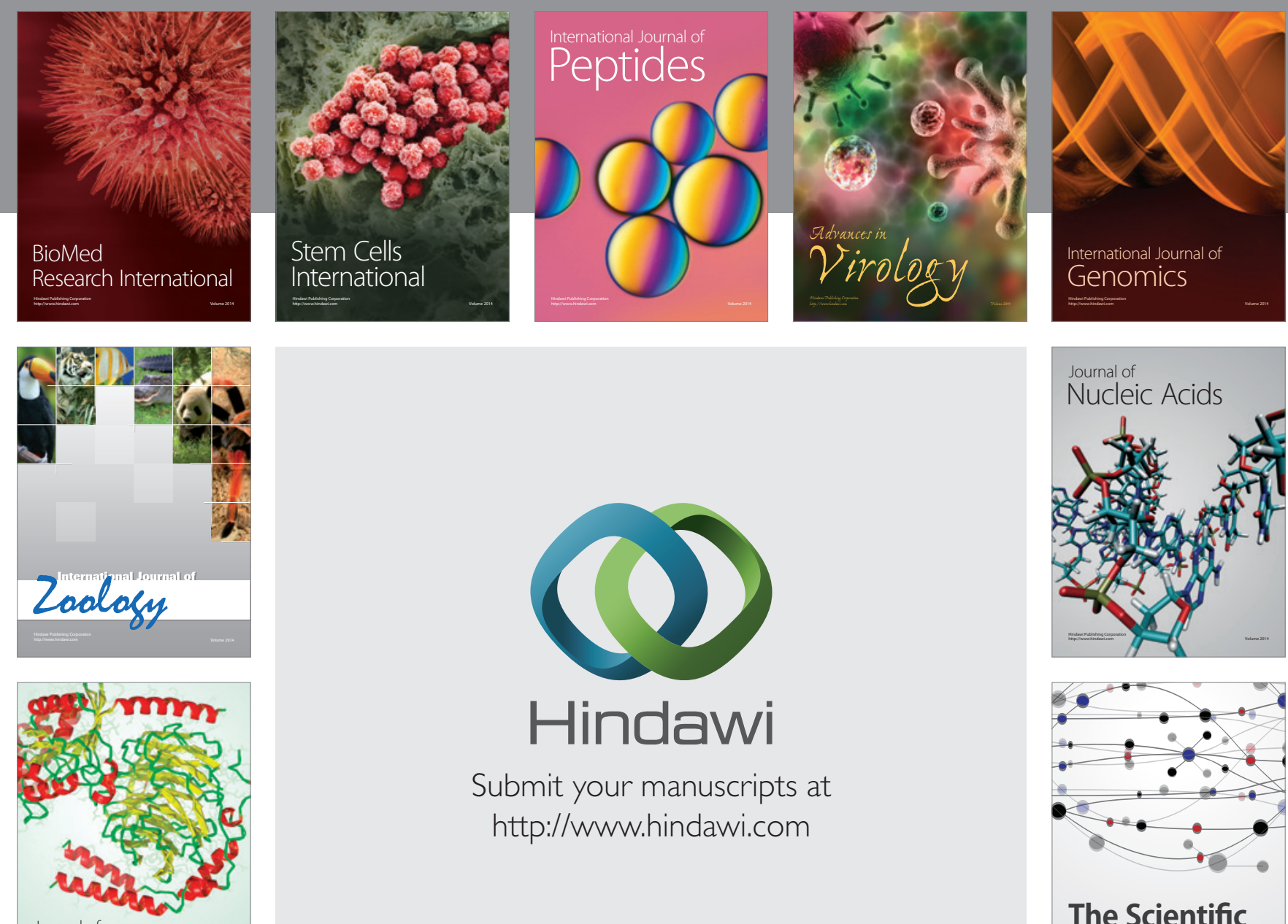

Submit your manuscripts at

http://www.hindawi.com

Journal of
Signal Transduction
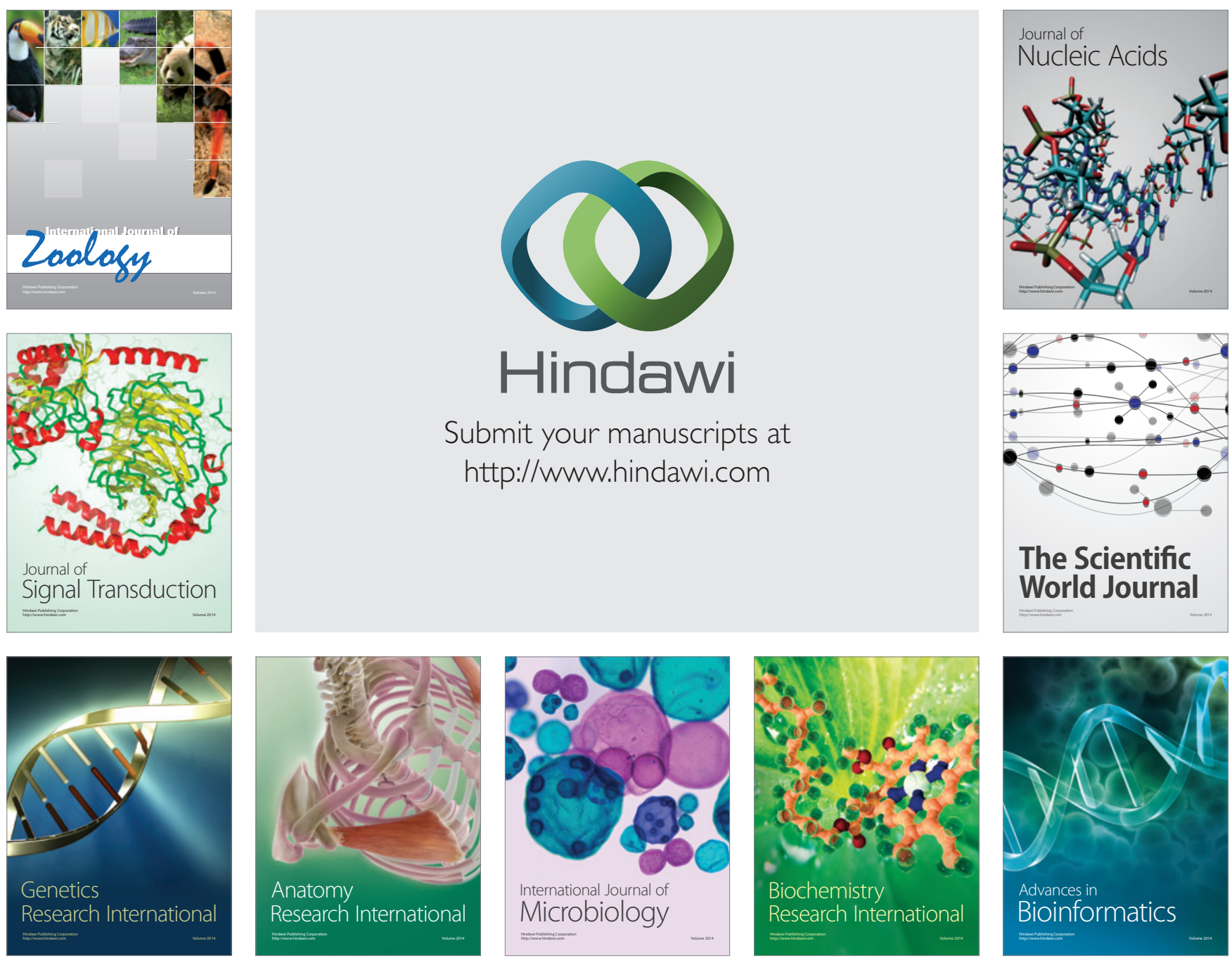

The Scientific World Journal
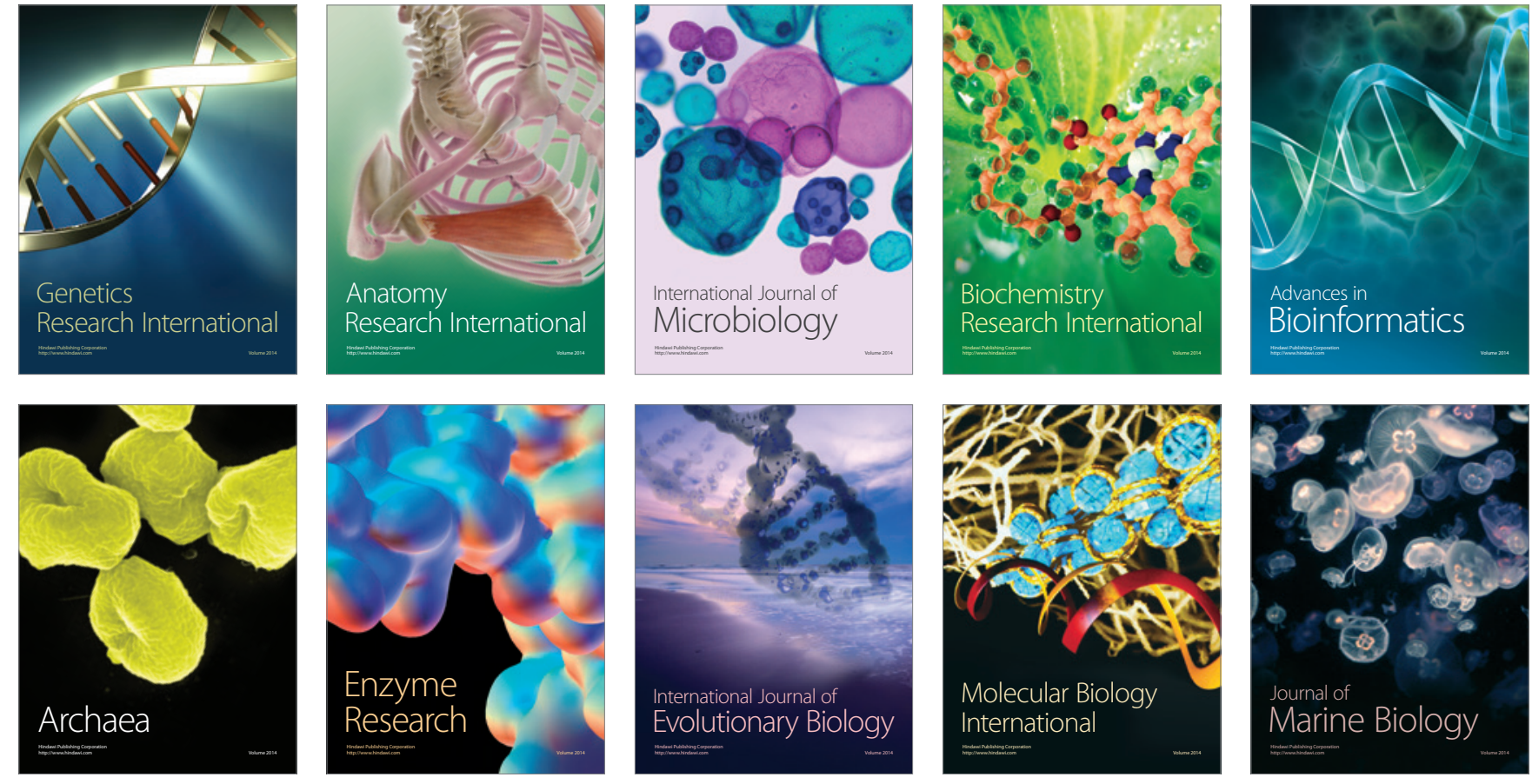